\title{
SALAT JUMAT SETELAH SALAT HARI RAYA ID SAAT PANDEMI COVID-19 DALAM PERSPEKTIF HUKUM ISLAM
}

\author{
Asri \\ Sekolah Tinggi Ilmu Islam dan Bahasa Arab (STIBA) Makassar \\ asri@stiba.ac.id \\ Zulfiah Sam \\ Sekolah Tinggi Ilmu Islam dan Bahasa Arab (STIBA) Makassar \\ zulfiahsam06@gmail.com

\section{Rezky Damayanti} \\ Sekolah Tinggi Ilmu Islam dan Bahasa Arab (STIBA) Makassar \\ Kikydamayanti88827@gmail.com
}

\begin{abstract}
Keywords :
ABSTRACT

Friday prayers, Eid prayers, pandemic, covid-19

This study aims to find out how the laws of Friday prayers after Eid prayer in an Islamic perspective and how the laws of Friday prayers after Eid prayers during the Covid-19 pandemic. The research method used is library research (library research), namely through literature review related to the above problems, with normative and historical approaches. The research results found are as follows; First, the law of Friday prayers after the Eid prayer is disputed by scholars in three views: First opinion: Friday prayers are compulsory for people who attend holiday prayers like Friday on any other day. Second opinion: Rukhșah is given to leave Friday prayers for Muslims who come from hamlets to the city to perform special prayers and Friday prayers. Third opinion: A person who has performed the Eid prayer, his obligation to perform Friday prayer is null and void, but it is appropriate for the priest to establish Friday prayers so that people who wish to attend them can attend. And for Muslims who have attended the holiday prayers, they are obliged to do the midday prayer on time if they do not do the Friday prayers. As for the law of implementing Friday prayers after the implementation of the Ied prayers in the midst of the Covid-19 pandema, the law of returning to the original law will still be mandatory for areas or zones that are still considered safe in carrying out Eid prayers in congregation
\end{abstract}

\section{Kata kunci :}

Salat jumat, salat ied, pandemic, covid-19

\section{ABSTRAK}

Penelitian ini bertujuan untuk mengetahui bagaimana hukum salat jumat setelah salat hari raya ied dalam perspektif Islam dan bagaimana hukum salat jum'at setelah salat ied di masa pandemi covid-19. Metode penelitian yang digunakan adalah penelitian kepustakaan (library reseach) yaitu melalui kajian literatur terkait 
BUSTANUL FUQAHA: Jurnal Bidang Hukum Islam

Vol. 1, No. 2 (2020) : Hal. 472-483

Website: https://journal.stiba.ac.id

permasalahan di atas, dengan pendekatan normatif dan historis. Hasil penelitian yang ditemukan adalah sebagai berikut; Pertama, hukum salat jumat setelah salat hari raya ied diperselisihkan ulama dalam tiga pendapat: Pendapat pertama: Salat jumat diwajibkan bagi orang yang menghadiri salat hari raya seperti jumat-jumat di hari yang lainnya. Pendapat kedua: Diberikan rukhṣah meninggalkan salat jumat bagi kaum muslimin yang datang dari dusun mendatangi kota untuk mengerjakan salat hari raya dan jumat secara khusus. Pendapat ketiga: Orang yang telah mengerjakan salat hari raya ied maka gugur kewajibannya mengerjakan salat jumat akan tetapi selayaknya imam mendirikan salat jumat agar bisa dihadiri oleh orang yang ingin menghadirinya. Dan bagi kaum muslimin yang telah menghadiri salat hari raya maka ia wajib mengerjakan salat dzuhur pada waktunya apabila ia tidak mengerjakan salat jumat. Adapun hukum pelaksanaan salat jumat setelah pelaksanaan salat ied di tengah pandema covid-19, maka hukumnya kembali kepada hukum asal akan tetap disyariatkannya untuk daerah atau zona yang masih dianggap aman dalam menjalankan salat ied secara berjamaah 


\section{PENDAHULUAN}

Ibadah adalah perkara yaitu mencakup seluruh apa yang dicintai dan diridhai Allah swt. baik berupa ucapan-ucapan atau perbuatan-perbuatan yang zahir (nampak) maupun yang batin (tersembunyi). ${ }^{1}$ Diantara contoh ibadah yang Allah swt. syariatkan adalah ibadah salat. Kedudukan salat dalam agama Islam sangat tinggi, karena salat merupakan tiang agama, salat adalah rukun yang kedua dari rukun-rukun Islam, yang pertama kali akan dihisab dari amalan seorang hamba pada hari kiamat dan yang membedakan antara muslim dan kafir. Rasulullah saw. bersabda:

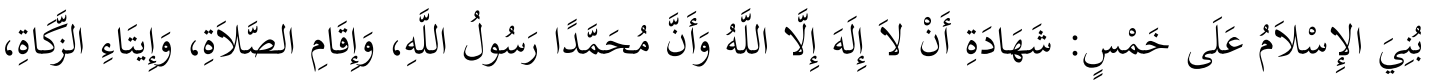

$$
\begin{aligned}
& 2{ }^{2}
\end{aligned}
$$

Artinya:

Islam dibangun atas lima perkara: persaksian bahwa tiada sesembahan yang berhak diibadahi selain Allah dan bahwa Nabi Muhammad adalah utusan Allah, menegakkan salat, menunaikan zakat, melaksanakan haji dan puasa bulan ramadhan.

Adapun pada hari jumat yang merupakan hari raya bagi kaum muslimin dalam sepekan, maka salat dzuhur hukumnya jatuh bagi kaum laki-laki yang memenuhi syarat untuk melaksanakan salat yang disyariatkan pada waktu itu yaitu salat jumat. Salat jumat adalah ibadah salat yang dikerjakan dua rakaat secara berjamaah setelah khutbah. Hukum salat jumat fardu ain bagi setiap muslim laki-laki yang merdeka sudah mukallaf (yang dibebani syariat), sehat serta muqīm (bukan dalam keadaan musafir). Allah swt. berfirman dalam Q.S. al-Jumu'ah/62: 9.

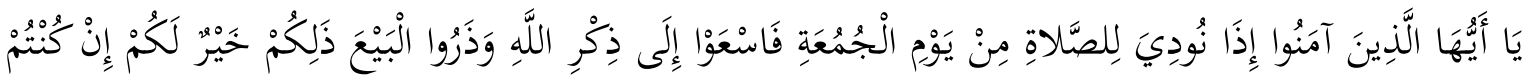

Terjemahnya:

Hai orang-orang beriman, apabila diseru untuk menunaikan salat Jumat, maka bersegeralah kamu kepada mengingat Allah dan tinggalkanlah jual beli, yang demikian itu lebih baik bagimu jika kamu mengetahui.

Pelaksanaan salat jumat berbeda dengan pelaksanaan salat lima waktu lainnya, karena salat jumat memiliki kekhususan yang tidak dimiliki oleh salat-salat lainnya, seperti dua khutbah yang mendahului salat jumat tersebut.

${ }^{1}$ Ṣālih bin 'Abdul 'Azīz bin Muḥammad Ālu al-Syekh, Ușūlul İmān (Cet. I; Kairo: I'lāmus Sunnah, 1432 H), h. 24.

${ }^{2}$ Muḥammad Ibnu Ismā'īl Ibnu Ibrāhīm Ibnu al-Mugīrah al-Ju'fī, Ṣạ̣ ị̣ al-Bukhāri (Cet. V; Riyāḍ: Maktabah al-Rusyd, 2014 M), h. 8.

${ }^{3}$ Kementerian Agama RI, Alquran dan Terjemah, h. 554. 
Salat dua hari raya (iedul fitri dan iedul adha) memiliki kesamaan dengan salat jumat yaitu memiliki dua khutbah dan jumlah rakaatnya sama yaitu dua rakaat. Hukum salat hari raya adalah sunnah makkadah, dimana Rasulullah saw. memerintahkan tiap laki-laki dan perempuan untuk melaksanakannya.

Permasalahan yang sekarang dihadapi oleh kaum muslimin adalah bertepatannya salat jumat dengan salat hari raya ied di musim pandemic covid-19 yang mana sebelumnya kdeua salat ini sempat dilarang oleh pemerintah demi untuk mencegah penyebaran covid-19. Melalui tulisan yang sederhana ini, penulis akan membahas tentang hukum salat jumat setelah salat hari raya ied pada musim covid-19 dalam perspektif hukum Islam, untuk menjawab permasalahan yang dihadapi oleh sebagian kaum muslimin.

Penulisan ini menggunakan metode pendekatan normatif dan didukung dengan pendekatan historis berupa kajian literatur kepustakaan (library research). Adapun data primer yang digunakan dalam pembahsan ini adalah penjelasan tentang buku-buku permasalahan fikih yaitu kitab-kitab yang ditulis oleh para ulama salaf seperti kitab yang membahas hukum-hukum yang berkenaan dengan judul penelitian ini serta ayat-ayat Alquran dan Hadis yang berkaitan dengan pembahasan dalam penelitian ini. Seperti dalam buku yang ditulis oleh Abū Mālik Kamāl Bin al-Sayyid Salim dengan judul Shahih Fiqhus Sunnah, Al-Rukhșahtu fī al-Șalāh, Terj. Sardinal, Rukhșah (KeringananKeringanan) dalam Salat oleh Abu Basal 'Alī, Minhatul 'Allam fi Syarhi Bulugil Maram oleh Abdullah bin Shalih al-Fauzan, al-Mulakhkhaṣ al-Fiqhī oleh Șalih bin Fauzān bin 'Abdullah al-Fauzan dan Muhammad bin Isma'il al-Amir al-Shan'ani dalam kitabnya Subulus Salam.

Adapun penelitian terkait hukum salat jumat setelah salat hari raya ied, adalah Penulisan yang dilakukan Amnu Rizal, mahasiswa UIN al-Raniry Darussalam-Banda Aceh yang berjudul "Hukum Salat Jumat Bertepatan Pada Hari Raya (Studi Komparatif Mażhab Syāfí'̄ dan Mażhab Hanbalī)," Dalam tulisan ini dibahas hukum salat jumat bertepatan hari raya dalam pandangan mażhab syāfi' '̄ dan mażhab Hanbalī dan metode istinbaṭ hukum yang digunakan mażhab syāfi' '̄ dan mażhab Ḥanbalī dalam menetapkan hukum salat jumat bertepatan salat hari raya. Begitu juga dengan penelitian yang berjudul Hukum Melaksanakan Salat Id Secara Personal (Munfarid) (Sebuah Solusi Pelaksanaan Salat Id Di Masa Wabah Covid-19) oleh Akhmad Hanafi Dain Yunta dan Asri, yang keduanya adalah dosen Sekolah Tinggi Ilmun Islam dan Bahasa Arab (STIBA) Makassar, yang di dalamnya dikupas tentang hukum salat ied secara personal dengan tetap memperhatikan pendekatan terhadap fatwa-fatwa para ulama klasik. 


\section{PEMBAHASAN}

\section{A. Analisis Hukum Salat Jumat Setelah Salat Hari Raya Ied dalam Perspektif Hukum Islam}

Ketika hari raya ied dan hari jumat bertemu dalam satu hari maka hukumnya diperselisihkan oleh ulama dalam tiga pendapat:

Pendapat pertama: Salat jumat diwajibkan bagi orang yang menghadiri salat hari raya seperti jumat-jumat di hari yang lainnya. Ini adalah pendapat jumhur ulama diantara mereka adalah Hanafiyyah, Mālikiyyah, dan Zahiriyyah. ${ }^{4}$

Mereka mendukung pendapat mereka dengan dalil-dalil berikut:

a. Allah swt.. berfirman dalam Q.S. Al-Jum'ah/ 62: 9.

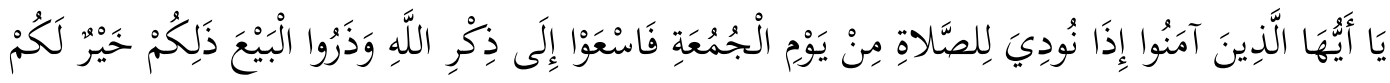

$$
\begin{aligned}
& \text { إِنْ كُنتِمْ تَعْلَمُونَ }
\end{aligned}
$$

Terjemahnya:

Hai orang-orang beriman, apabila diseru untuk menunaikan salat jumat, maka bersegeralah kamu kepada mengingat Allah dan tinggalkan jual beli. ${ }^{5}$

b. Dari Ibnu 'Umar dan Abū Hurairah ra., bahwa keduanya mendengar Rasulullah saw. bersabda di atas kayu-kayu mimbarnya, "Pasti ada kaum meninggalkan salat jumat sehingga Allah mengunci mati hati mereka kemudian mereka menjadi orang-orang yang lalai." 6

Dalil-dalil menunjukkan kewajiban melakukan salat jumat yang secara umum menghilangkan sumber perbedaan pendapat.

1) Salat jumat adalah salat fardu sedangkan salat hari raya adalah sunnah dan sunnah tidak menggugurkan yang wajib.

2) Qiyās: Ulama sepakat mengatakan bahwa salat dzuhur tidak gugur kewajiban mengerjakannya karena telah mengerjakan salat hari raya dengan salat jumat, karena keduanya adalah sama-sama salat yang wajib sehingga salah satunya tidak bisa gugur dengan yang lainnya. ${ }^{7}$

\footnotetext{
4،Alī Abūl Bașal, Al-Rukhṣahtu fi al-Ṣalāh, Terj. Sardinal, Rukhṣah (Keringanan-Keringanan) dalam Salat (Cet. I; Jakarta Timur: Akbar Media, 2011M), h. 218.

${ }^{5}$ Kementerian Agama RI, Alquran dan Terjemah (Cet I; Jawa Barat: Syāmil, 2012 M), h. 554.

${ }^{6}$ Abūl Ḥasan Muslim Ibnu Hajjāj al-Qusyairī al-Naisabūrī, Sahịḥ Muslim (PT. Dār 'Ibādi alRaḥmān, 2011 M), h. 208.

7،Alī Abūl Bașal, Al-Rukhșahtu fi al-Ṣalāh, Terj. Sardinal, Rukhșah (Keringanan-Keringanan) dalam Salat, h. 218.
} 
Adapun keringanan meninggalkan salat jumat bagi siapa yang telah melaksanakan salat hari raya dikhususkan bagi orang yang diwajibkan atasnya salat jumat dari penduduk dusun yang mendatangi kota untuk mengerjakan salat hari raya ied. ${ }^{8}$

Dari Abū 'Ubaid ia berkata:

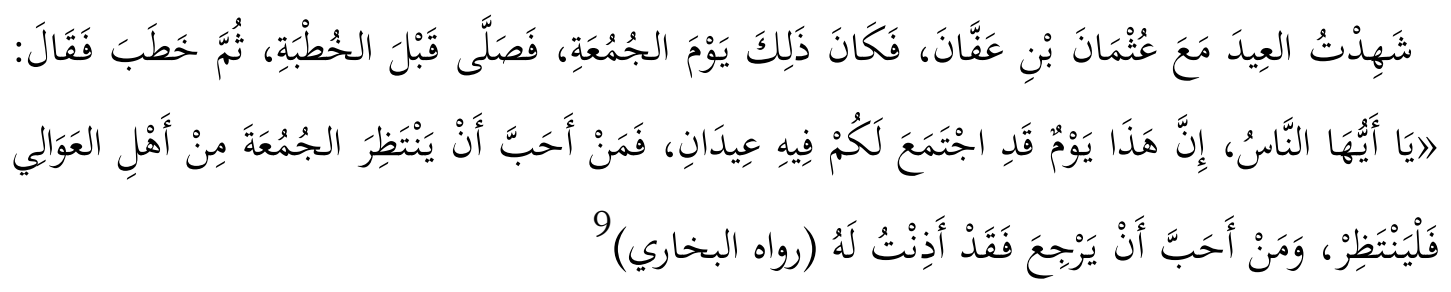

Artinya:

Beliau pernah bersama Uṡmān bin 'Affān ra., dan hari tersebut adalah hari jumat. Kemudian beliau salat ied sebelum khutbah. Lalu beliau berkhutbah dan berkata, "Wahai sekalian manusia sesungguhnya ini adalah hari dimana terkumpul dua hari raya (dua hari ied), siapa saja yang tidak menetap dan ingin menunggu salat jumat maka silahkan. Namun siapa saja yang ingin pulang, maka silahkan dan telah kuizinkan."

Pendapat kedua: Diberikan rukhṣah meninggalkan salat jumat bagi dusun yang mendatangi kota untuk mengerjakan salat hari raya dan jumat secara khusus. Ini adalah pendapat Syāfi' 'ìyyah. ${ }^{10}$ Dikarenakan sulit bagi mereka untuk kembali karena jauhnya tempat tinggal mereka. ${ }^{11}$ Al-Nawawī mengatakan, "Jika hari raya bertemu dengan hari jumat dan penduduk kampung yang panggilan azan sampai kepadanya, dan mereka telah menghadiri salat hari raya dan mereka mengetahui bahwa jika mereka kembali pasti mereka akan ketinggalan salat jumat maka mereka boleh pergi dan meninggalkan salat jumat pada hari ini menurut pendapat yang shahih yang diputuskan di dalam qawl qadīm (pendapat Imam Syāfi'ī ketika menetap di Iraq) dan qawl jadīd (ketika Imam Syāfi'ī menetap di Mesir) dan pendapat yang syaż (aneh) adalah wajib bagi mereka bersabar menunggu salat jumat.

Sedangkan berhubungan dengan penduduk kota, maka kewajiban salat jumat gugur dari mereka tanpa ada perbedaan pendapat di kalangan Syāfi'īyyah. Mereka

\footnotetext{
${ }^{8}$ Abū Mālik Kamāl bin al-Sayyid Sālim, Șậ̄ḥ Fiqhus Sunnah, jilid I (Cet. I; Kairo: Dārul Tuafiqiyah, $1721 \mathrm{M})$, h 523.

${ }^{9}$ Muḥammad Ibnu Ismā'îl Ibnu Ibrāhīm Ibnu al-Mugīrah al-Ju'fī, Ṣahīh al-Bukhānī (Cet. V; Riyāḍ: Maktabah al-Rusyd, 2014 M), h. 791.

10،Alī Abūl Baṣal, Al-Rukhṣahtu fi al-Ṣalāh, Terj. Sardinal, Rukhṣah (Keringanan-Keringanan) dalam Salat, h. 219.

11 ، Abdullāh bin Șāliḥ al-Fauzān, Minhatul 'Allam fi Syarḥi Bulūgil Marām, jilid 4 (Cet. IX; Arab Saudi: Dār Ibnu al-Jauzī, 1438 H), h. 51.
} 
berdalil dengan keterangan yang terdapat di dalam khutbah Uṡmān bin 'Affān ra., dimana ia mengatakan, "Sesungguhnya pada hari kalian ini telah bertemu dua hari raya maka siapa diantara penduduk yang tinggal di al-'Alyah ingin menunggu jumat maka tunggulah dan barangsiapa yang ingin kembali maka telah aku izinkan. ${ }^{12}$

Pendapat ketiga: Orang yang telah mengerjakan salat hari raya maka gugur kewajibannya mengerjakan salat jumat akan tetapi selayaknya imam mendirikan salat jumat agar bisa dihadiri oleh orang yang ingin menghadirinya dan orang yang telah menghadiri salat hari raya maka ia tidak mempunyai kewajiban lain selain mengerjakan salat ashar pada hari itu. Ini adalah pendapat Ața' bin Abī Rabah. ${ }^{13}$ Dan ini juga merupakan pendapat kebanyakan ulama Hanābilah. ${ }^{14}$ 'Abdul 'Aẓīm bin Badawī al-Khalafī mengatakan, "Apabila hari raya jatuh pada hari jumat, maka gugur kewajiban salat jama'ah jumat bagi orang-orang yang sudah mengerjakan salat jama'ah ied." 15

Hanābilah mengatakan jika ia mendahulukan salat hari raya maka ia perlu mengerjakan salat dzuhur pada waktunya apabila ia tidak mengerjakan salat jumat dan jika ia mendahulukan salat jumat maka gugur darinya kewajiban mengerjakan salat hari raya. Dan menggugurkan disini adalah menggugurkan hukum menghadirinya bukan menggugurkan kewajibannya sehingga hukumnya sama dengan hukum orang yang sakit dan orang yang mempunyai uzur yang sejenisnya atau orang yang mempunyai kesibukan yang membolehkannya meninggalkan salat jumat. Namun kewajiban tidak gugur darinya karena menggugurkan disini adalah untuk meringankan dan jika ia mengerjakan maka salatnya sah dan boleh baginya mengimaminya.

Sedangkan imam tidak gugur kewajibannya menghadiri salat jumat karena jika ia meninggalkannya, maka sulit dikerjakan oleh orang yang wajib mengerjakannya, dan orang yang ingin mengerjakannya walaupun ia tidak mempunyai kewajiban mengerjakannya. Oleh karena itu, jika sekelompok orang yang sudah memenuhi jumlah untuk melaksanakan salat jumat maka imam berkewajiban mendirikannya dan jika belum memenuhi maka ia mengerjakan salat dzuhur. Dan berdasarkan riwayat bahwa salat jumat tidak gugur dari imam maka orang yang wajib mengerjakan salat jumat mesti hadir bersamanya sehingga jumat disini dianggap fardu kifāyah dan kewajibannya gugur dengan hadirnya empat puluh orang. Sedangkan orang yang tidak

\footnotetext{
12،Alī Abūl Baṣal, Al-Rukhṣahtu fi al-Ṣalāh, Terj. Sardinal, Rukhṣah (Keringanan-Keringanan) dalam Salat, h 219.

13، Alī Abūl Bașal, Al-Rukhṣahtu fi al-Ṣalāh, Terj. Sardinal, Rukhṣah (Keringanan-Keringanan) dalam Salat, h. 220.

${ }^{14}$ Abū Mālik Kamāl Bin al-Sayyid Sālim, Sạ̣ị̣ Fiqhus Sunnah, h. 523.

15، Abdul 'Aẓīm bin Badawī al-Khalafî, Al-Waj̄z fi Fiqhis Sunnah wal-Kitā bil 'Az̄̃z(Cet. III; Mesir: Dār Ibnu Rajab 1421 H), h. 155.
} 
ikut salat hari raya bersama imam maka wajib bersegara menuju salat jumat baik mereka mencapai jumlah orang yang ditetapkan untuk salat jumat atau tidak, mengenai ini hanya ada satu pendapat dikalangan Hanābilah. Dan gugur juga kewajiban melaksanakan salat jumat jika dikerjakan sebelum atau setelah tergelincir matahari, tidak ada kewajiban hingga salat ashar, karena salat jumat. Apabila telah gugur kewajiban mengerjakannya karena mengerjakan salat hari raya lebih utama lagi untuk digugurkan. ${ }^{16}$

Dalil-dalil pendapat ini adalah seperti berikut ini:

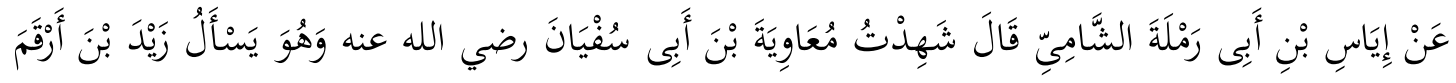

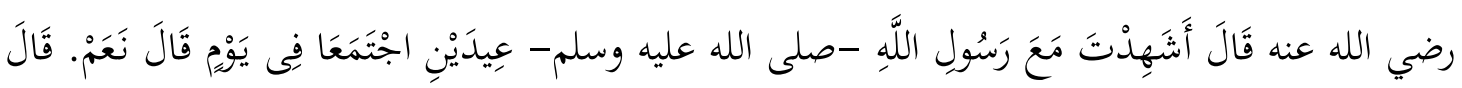

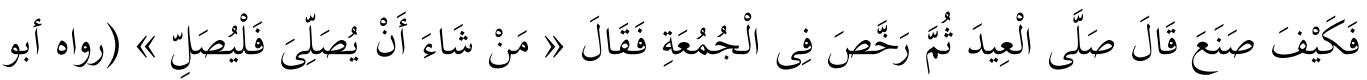

$$
\begin{aligned}
& { }^{17}
\end{aligned}
$$

Artinya:

Dari Iyās bin Abī Ramlah al-Syām, beliau berkata: “Aku pernah menyaksikan Mu'āwiyah bin Ab̄̄ Sufyān ra., bertanya kepada Zaid bin Arqām ra.,: "Apakah kamu pernah bersama Rasulullah saw. terjadi dua ied terkumpul dalam satu hari?", ia menjawab: "Iya (pernah)", Mu'awiyah bertanya: "Bagaimanakah yang beliau lakukan", ia menjawab: "Beliau saw. salat ied kemudian memberikan keringanan untuk salat jumat, beliau bersabda: "Barangsiapa yang hendak salat maka salatlah ia".

Dari Abū Hurairah ra., bahwasanya Rasulullah saw. bersabda:

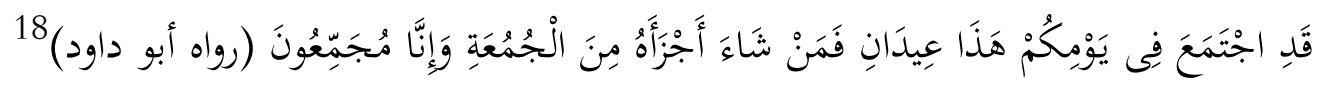
Artinya:

Pada hari ini terkumpul bagi kalian dua hari raya, barang siapa yang ingin mencukupkan dengan (salat ied) dari salat jumat, maka itu cukup baginya, tetapi kami tetap salat jumat bersama".

Dari seorang tabi' in bernama Atha'bin Abi Rabah, ia berkata:

16، Alī Abūl Baṣal, Al-Rukhṣahtu fi al-Ṣalāh, Terj. Sardinal, Rukhṣah (Keringanan-Keringanan) dalam Salat, h. 220-221.

${ }^{17}$ Abū Dāwud Sulaimān ibnu al-Asy'aś al-Sijistānī, Sunan Abī Dāwud, h. 298.

${ }^{18}$ Abū Dāwud Sulaimān ibnu al-Asy’aś al-Sijistānī, Sunan Abī Dāwud, h. 299. 


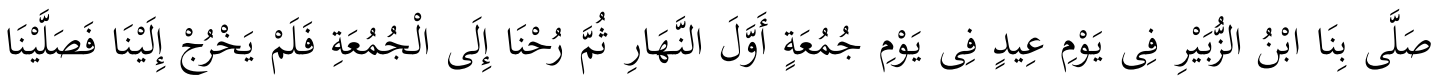

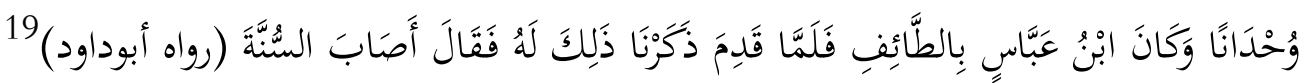

Artinya:

Ibnu al-Zubair ketika hari ied yang jatuh pada hari jumat pernah salat ied bersama kami di pagi hari. Kemudian ketika tiba waktu slata jumat Ibnu alZubair tidak keluar, beliau hanya salat sendirian. Tatkala Ibnu 'Abbās berada di Țaif. Ketika Ibnu 'Abbās tiba, kami pun menceritkan kelakuan Ibnu alZubair pada Ibnu 'Abbās. Ibnu 'Abbās mengatakan "Ia adalah orang yang menjalankan ajaran Nabi saw. (așhāâus sunnah).

Dalil-dalil ini menunujukkan dengan jelas bahwa Rasulullah saw. telah memberika rukhṣah untuk meninggalkan salat jumat bagi orang telah mengerjakan salat hari raya. Dalil akal dari pendapat ini, maksud berkumpul telah terjadi dengan mengahadiri salat hari raya, kemudian ia mengerjakan salat dzuhur apabila ia tidak menghadiri salat jumat, maka salat dzuhur dikerjakan pada waktunya dan salat hari raya telah mencapai maksud didirikannya salat jumat. Dan mewajibkannya kepada manusia adalah memberatkan mereka dan mengulangi maksud berkumpulnya mereka dan bergembira serta bersuka cita yang dianjurkan bagi mereka melakukannya di hari itu. Jika mereka ditahan mengerjakan semua itu maka maksud mendirikan salat hari raya akan hilang.

Hari jumat adalah hari raya dan iedul fitri dan iedul adha juga merupakan hari raya dan diantara kebiasaan syar'ī (agama) adalah jika dua ibadah yang satu jenis berkumpul maka salah satunya dimasukkan kepada yang lain sebagaimana wudhu telah termasuk di dalam mandi dan salah satu mandi telah mencakup mandi karena yang lain. ${ }^{20}$

\section{B. Hukum salat jum'at setelah salat ied di masa pandemi covid-19}

Corona virus Disease 2019 atau COVID-19 adalah penyakit baru yang dapat menyebabkan terjadinya gangguan pernapasan dan radang paru. Penyakit ini disebabkan oleh infeksi Severe Acute Respiratory Syndrome Coronavirus 2 (SARSCoV-2). Gejala klinis yang muncul beragam, seperti gejala flu biasa (demam, batuk, pilek, nyeri tenggorokan, nyeri otot, nyeri kepala) sampai yang komplikasi berat. Adapun cara penularannya melalui droplet/ percikan saat batuk, bersin atau berbicara,

\footnotetext{
${ }^{19}$ Abū Dāwud Sulaimān ibnu al-Asy’as al-Sijistānī, Sunan $A b \bar{i}$ Dā wud, h. 298.

20،Alī Abūl Bașal, Al-Rukhșahtu fi al-Ṣalāh, Terj. Sardinal, Rukhșah (Keringanan-Keringanan)
} dalam Salat, h. 223-224. 
kontak fisik dengan orang yang terinfeksi (menyentuh atau berjabat tangan) atau dengan menyentuh mulut, hidung dan mata dengan tangan yang terpapar virus. ${ }^{21}$

Fenomena muculnya pandemi covid-19 yang menyebar di nusantara secara nasional, yang memicu berbagai reaksi dalam menhadapinya utamanya dalam menanggulangi dan mencegah penyebaran covid-19 yang dikhawatirkan akan merebak dengan cepat sebagaimana yang marak pemberitaannya dari negeri asalnya china tepatnya provinsi wuhan.

Hal inipun yang mendorong pemerintah untuk memberikan respon dan tindakan cepat dengan mengeluarkan edaran-edaran yang berisi penjelasan tentang bahaya covid-19 sekaliguas himbaun kepada masyarakat untuk mengikuti dan mematuhi protocol kesehatan dalam mencegah tersebarnya covid-19.

Dan di antara bentuk himbauan pemerintah yang dituangkan baik dalam bentuk Kepres, Permen atau bahkan dalam bentuk Undang-undang, begitu juga dengan MUI yang tertuang dalam fatwanya dalam hal ini adalah bahwa dalam rangka memutus mata rantai penyebaran covid-19 maka segala macam bentuk aktivitas yang berpotensi mengumpulkan banyak orang sebisa mungkin untuk diminimalisir, termasuk dalam hal ini adalah salat-salat berjamaah, baik salat-salat rawatib, salat jumat maupun salat ied. Berdasarkan keputusan dan peraturan tersebut, maka masjid-masjid dihimbau untuk tidak dibuka pada tiap waktu salat namun tetap dikumandangkan azan dengan menambah lafaz Shallu fi buyutikum. ${ }^{22}$

Tindakan dan langkah seperti ini diambil oleh pemerintah tentunya sebagai tindakan preventif (sad al dzaria'ah) dalam menghadang penyebaran virus corona. ${ }^{23}$ Begitu juga dalam hal upaya pencegahan ini sering terjadi benturan antara maslahat dan mafsadat, namun dalam kaedah fikih disebutkan ; "Jika tuntutan dan larangan berpadu, maka prioritasnya adalah larangan" ${ }^{24}$. Maka penetapan untuk ditiadakannya salat berjamaah selaras dengan kaidah di atas, dan kaidah; menolak keburukan (mafsadah) lebih diutamakan daripada meraih kebaikan (maslahah). ${ }^{25}$ Hal inipun berimplikasi pada pelaksanaan salat iedul fitri yang dihimbau dilaksanakan masing-

${ }^{21}$ Dumilah Ayuningtyas, ed., Bunga Rampai Covid-19: Buku Kesehatan Mandiri Untuk Sahabat̃irumahaja (Depok: PDProkami Kota Depok, 2020), 7-8.

${ }^{22}$ Muhammad Yusram, Azan Dan Kaifiatnya Di Tengah Wabah Covid-19, BUSTANUL FUQAHA: Jurnal Bidang Hukum Islam Vol. 1, No. 2 (2020) Special Issue : Islamic Law Perspective on Covid-19 : Hal. 186.

${ }^{23}$ M. Nur Kholis Al Amin, Menakar Nilai Kemanfaatan dari Penangguhan Walimat Al- 'Ursy Di Masa Darurat COVID-19 Melalui Sadd Adz-Dzari'ah, Ulumuddin: Jurnal Ilmu-ilmu Keislaman(p)ISSN: 1907-2333 (e)ISSN: 2685-9211 https://jurnal.ucy.ac.id/index.php/agama_islam Volume 10 Nomor 1, Juni 2020, 27-38 1976), 29.

${ }^{24}$ Asjmuni A. Rahman, Qa'idah-Qa'idah Fiqih (Qowa'idul Fiqhiyah) (Jakarta: Bulan Bintang,

${ }^{25}$ Abdul Hamid Hakim, Mabadi Awaliyah (Jakarta: Maktabah Sakdiah Putra, n.d.); Hifdhotul Munawwaroh, "Sadd Al-Dzari'ah Dan Aplikasinya Pada Permasalahan Fiqih Kontemporer," Ijtihad : Jurnal Hukum dan Ekonomi Islam 12, no. 1 (2018): 63; Takhim, “Saddu Al- Dzari 'ah” 
masing di rumah saja bersama kelaurga satu rumah, yang akhirnya membutuhkan pembahasan khusus tentang hukum pelaksanaan salat ied secara munfarid, tanpa berjamaah. ${ }^{26}$

Namun dalam kondisi belakangan ini, pemerintah sudah memberikan kelonggaran untuk melaksanakan salat berjamaah dengan tetap menjaga protocol kesehatan, seperti menjaga jarak, memakai masker, mencuci tangan dengan hand sanitizer baik ketika masuk maupun keluar masjid dan tidak berjabat tangan. Sehingga berdasarkan hal ini, pelaksanaan salat iedpun kemungkinan besar akan ada peluang untuk tetap diadakan secara berjamaah dengan tetap memperhatikan dan menjaga protocol kesehatan yang telah disebutkan. Dan berdasarkan ini pula, ketika pelaksanaan iedul adha dapat dikerjakan secara berjamaah, maka tentunya pelaksanaan salat jum'atpun yang bertepatan dengan hari ied inipun dapat dikerjakan dengan menjalankan protokolat kesehatan

\section{KESIMPULAN}

Berdasarkan uraian di atas dapat disimpulkan bahwa hukum salat jumat setelah salat hari raya ied dalam perspektif hukum Islam, hukumnya diperselisihkan menjadi tiga pendapat: Pendapat pertama: Salat jumat diwajibkan bagi orang yang menghadiri salat hari raya seperti jumat-jumat di hari yang lainnya. Pendapat kedua: Diberikan rukhșah meninggalkan salat jumat bagi kaum muslimin yang datang dari dusun mendatangi kota untuk mengerjakan salat hari raya dan jumat secara khusus. Dikarenakan sulit bagi mereka untuk kembali karena jauhnya tempat tinggal mereka. Pendapat ketiga: Orang yang telah mengerjakan salat hari raya maka gugur kewajibannya mengerjakan salat jumat akan tetapi selayaknya imam mendirikan salat jumat agar bisa dihadiri oleh orang yang ingin menghadirinya. Dan bagi kaum muslimin yang telah menghadiri salat hari raya maka ia wajib mengerjakan salat dzuhur pada waktunya apabila ia tidak mengerjakan salat jumat. Adapun hukum pelaksanaan salat jumat setelah pelaksanaan salat ied di tengah pandema covid-19, maka hukumnya kembali kepada hukum asal akan tetap disyariatkannya untuk daerah atau zona yang masih dianggap aman dalam menjalankan salat ied secara berjamaah.

\section{DAFTAR PUSTAKA}

A. Rahman, Asjmuni. (1976). Qa'idah-Qa'idah Fiqih (Qowa'idul Fiqhiyah). Jakarta: Bulan Bintang.

Abū 1 Baṣ al, 'Alī , Al-Rukhṣ ahtu fi al-Ṣ alä h, Terj. Sardinal (2011). Rukhṣ ah

${ }^{26}$ Akhmad Hanafi Dain Yunta dan Asri, , BUSTANUL FUQAHA: Jurnal Bidang Hukum Islam Vol. 1, No. 2 (2020) Special Issue : Islamic Law Perspective on Covid-19 : Hal. 262-271. 
BUSTANUL FUQAHA: Jurnal Bidang Hukum Islam

Vol. 1, No. 2 (2020) : Hal. 472-483

Website: https://journal.stiba.ac.id

(Keringanan-Keringanan) dalam Salat, Cet. I; Jakarta Timur: Akbar Media.

Al Amin, M. Nur Kholis. (2020). Menakar Nilai Kemanfaatan dari Penangguhan Walimat Al-'Ursy Di Masa Darurat COVID-19 Melalui Sadd Adz-Dzari'ah, Ulumuddin: Jurnal Ilmu-ilmu Keislaman. Vol.10, No.1.

al-Fauzā n, 'Abdullā h bin Ș à liḥ . (1438 H). Minhatul 'Allam fí Syarḥ i Bulū gil

Marā m, jilid 4 (Cet. IX). Arab Saudi: Dā r Ibnu al-Jauz.

Ayuningtyas, Dumilah ed. (2020). Bunga Rampai Covid-19: Buku Kesehatan Mandiri

Untuk Sahabațirumahaja. Depok: PD Prokami Kota Depok.

Hakim, Abdul Hamid. (t.th). Mabadi Awaliyah. Jakarta: Maktabah Sakdiah Putra.

Munawwaroh, Hifdhotul. (2018). "Sadd Al- Dzari'ah Dan Aplikasinya Pada Permasalahan Fiqih Kontemporer," Ijtihad : Jurnal Hukum dan Ekonomi Islam 12, no. 1 : 63; Takhim, "Saddu Al- Dzari 'ah"

Ibnu al-Asy'aś al-Sijistā nī , Abū Dā wud Sulaimā n. (1430). Sunan Abì Dā wud, jilid II (Cet. I). Bairut/Lebanon: Dà rur al-Risā lah al-‘'̄ lamiyyah.

Ibnu al-Mugì rah al-Ju'fì , Mụ ammad Ibnu Ismā 'ì 1 Ibnu Ibrā hì m. (2014). $S S$ ah ịh al-Bukhā ri Cet. V. Riyā d : Maktabah al-Rusyd.

Ibnu Badawi al-Khalafì , 'Abdul 'Az i m. (1421 H). Al-Waji $z$ fi Fiqhis Sunnah walKitā bil 'Aż̃ $z$ (Cet. III). Mesir: Dā r Ibnu Rajab.

Ibnu Ḥ ajjā j, Abū 1 Ḥ asan Muslim al-Qusyairī al-Naisabū rī .(2011). Ș ạ ị Muslim. PT. Dà r 'Ibā di al-Raḥ mà n.

Ibnu Muh ammad Ā lual-Syekh, Ș à liḥ bin 'Abdul 'Azì z. (1432 H). Uș ù lulI mā $n$ (Cet. I). Kairo: I'lā mus Sunnah.

Kementerian Agama RI. (2012). Alquran dan Terjemah (Cet I). Jawa Barat: Syā mil.

Sà lim, Abū Mà lik Kamā 1 bin al-Sayyid (1721 M). Ș ạ ì ḥ Fiqhus Sunnah, jilid I (Cet. I). Kairo: Dà rul Tuafiqiyah.

Yunta, Akhmad Hanafi Dain., Asri (2020). Hukum Melaksanakan Salat Id Secara Personal (Munfarid) (Sebuah Solusi Pelaksanaan Salat Id Di Masa Wabah Covid19), BUSTANUL FUQAHA: Jurnal Bidang Hukum Islam Vol. 1, No. 2 Special Issue : Islamic Law Perspective on Covid-19.

Yusram, Muhammad. (2020). Azan Dan Kaifiatnya Di Tengah Wabah Covid-19, BUSTANUL FUQAHA: Jurnal Bidang Hukum Islam Vol. 1, No. 2 Special Issue : Islamic Law Perspective on Covid-19. 